\title{
The Importance of Zakat Distribution and Urban-Rural Poverty Incidence among Muallaf (New Convert)
}

\author{
Fuadah Johari ${ }^{1}$, Ahmad Fahme Mohd Ali ${ }^{1}$, Muhammad Ridhwan Ab Aziz ${ }^{1}$ \& Nursilah Ahmad ${ }^{1}$ \\ ${ }^{1}$ Faculty of Economics and Muamalat, Universiti Sains Islam Malaysia (USIM), Negeri Sembilan, Malaysia. \\ Correspondence: Fuadah Johari, Faculty of Economics and Muamalat, Universiti Sains Islam Malaysia (USIM), \\ Negeri Sembilan, Malaysia. E-mail: fuadah@usim.edu.my
}

Received: May 9, 2014 Accepted: September 9, 2014 Online Published: October 30, 2014

doi:10.5539/ass.v10n21p42 URL: http://dx.doi.org/10.5539/ass.v10n21p42

\begin{abstract}
This study demonstrates literately the importance of regional (urban-rural) differences and the impact of zakat distribution towards the poverty alleviations among asnaf Muallaf. This study was motivated by the monthly official zakat distribution towards asnaf Muallaf that did not differentiate the true urban-rural cost of living differences. Differences in urban and rural poverty lines that did not reflect the actual urban-rural cost of living differences will provide a misleading picture of the distributional impact of development, which usually involves urban sector expansion. In a dualistic economy, one of the ways the poor benefit from development is through expansion of job opportunities in the modern predominantly urban sector, in addition to increases in productivity in the traditional predominantly rural sector. Thus, this study aims to identify the dispersal of Muallaf in terms of urban-rural poverty that involved in allocation of zakat distribution. In defining poverty between urban and rural areas, therefore, one should ensure the differences in the cost of living between these two areas. The finding suggest that, a huge of amount of zakat been allocated to the development of asnaf Muallaf in the state of Selangor especially in urban area. However, most of zakat distribution on Muallaf goes to urban region which higher in cost of living without considering a set of prices including a broader bundle of goods and services representative of the purchases of consumers in different region.
\end{abstract}

Keywords: Muallaf, Zakat allocation, urban-rural poverty, Selangor Islamic Religious Department (MAIS)

\section{Introduction}

Zakat is one of the pillars of faith in Islam that emphasizes socio-economic development. Any discussion on zakat in the context of worship cannot be disconnected from the socio-economic factor, especially in aiding the underprivileged based on the Maslahat concept (al Qardhawi, 1987). From the Fiqh point of view, zakat can produce a certain amount from a specific wealth for the benefit of those who are entitled to receive it as stipulated by Allah (Ibn. Qudamah 1968). The primary purpose of zakat is to redistribute wealth of the society among the poor (Siddiqui, 1978). The administration of zakat involves at least two broad aspects, namely the collection and allocation. The role of the state in collecting and allocation zakat fund began rather lately during the Holy Prophet's time in Medina. Zakat funds were distributed among the eight categories of beneficiaries as stated in the Quran. Allah s.w.t has determined these categories when He s.w.t says:

"Sadaqat are for the poor and the needy, and those employed to administer (the Zakat), for those whose hearts are to be won over, and for the freeing of human beings from bondage, and (for) those who are burdened with debts, and (for every struggle) in Allah's cause, and (for) the wayfarer: (this is) an ordinance from Allah, Allah is All-Knowing, full of Wisdom."

(9:60)

Muallaf (new convert/ reconciliation of hearts) defined as Muallaf-al-Qulub as refers to a persons who converted or revert to Islam regardless of races and nation. In principle, this includes those people who giving full co-operation in contributing and strengthening Islam. This includes those who are newly converted to Islam who might have lost their place to depend such as family, friend and in worst case their work. Therefore they are economy and mentally weak and need assistance and encouragement. The purpose of the financial assistance is to strengthen their belief (Iman) by providing them financially and morale support that create the sense of belonging to Islamic ummah. Beside new converting Muslims, most of previous Islamic scholar also include the term Muallaf to the non-Muslims, but only for the purpose of turning their hearts to Islam (al-Qaradawi 1986:). Al-Qurtubi (1954) mentioned two of them, which are: 
1. The Leaders and public figures amongst them who had many friends who were non-Muslims. By giving them a part of the zakat, it was hoped to be able to attract them and their friends and get them to embrace Islam.

2. The middlemen who can persuade other non-Muslims to embrace and accept Islam such as an act of war. On this matter, they received a part of the zakat to become such a middleman.

Zakat distribution can prevent the Muallaf from deeds that may spark social unrest that comes from family and society. It some sort of education for them to realize that Islam is a wholesomeness (Shumul) religion and strengthen their belief that there are on the right path of becoming Muslims and thus further encourage them to hope for the blessing of Allah, so that their hearts are open to accept the teaching of Islam (Al-Qurtubi, 1954). According to Ibn Hisham (704 - 770) the purpose of providing guidance to the Muallaf in the basic knowledge of the 'Deen' (religion) and instilling them with qualities of precise moral behaviour is to encourage them to willingly embrace Islam, and to avoid evil deeds (Ibn Hashim, 1955). Thus, zakat plays significant role 'to win' and 'to soften' the heart of the Muallaf to follow Islam as a way of life.

The urban and rural region has a different phenomenon of poverty. The Malaysia's zakat state department had recently acknowledged the importance of the urban and rural cost of living differences in distributing zakat but considered only zakat distribution among the poor (Fuqara) and hardcore poor (Masakin) (JAWHAR, 2007; MAIS 2013). The problem raise here is that, most academics acknowledged the importance of the adjustment to the urban rural cost of living in poverty studies (Sicular et al., 2007, Sahn et al., 2003, Ravallion, 2007, Dodoo et al., 2007). However, in the absence of separate of amount zakat distribution between urban and rural areas, some researchers adopted rough adjustment based on the average prices difference between urban and rural areas. Thus, this study aims to identify the dispersal of Muallaf in terms of urban-rural poverty that involved in allocation of zakat distribution. In defining poverty between urban and rural areas, therefore, one should ensure that they take into account differences in the cost of living across these areas. These different phenomenon of poverty between urban and rural area is significant to make the zakat distribution becomes more effective.

\section{Poverty in Islam}

Poverty in Islam is concerned with insufficiency of income or expenditure and the inability in fulfilling basic human needs. There are no distinct techniques to measure poverty, as it is always associated with some level of income or expenditure required to provide for the basic human needs. This human needs refer to the right of food, clothes and shelter as pronounced by the Prophet Muhammad that are to be identified and met in order to sustain a minimum standard of living. The poverty line or income level, which serves as an indicator to identify whether a person is poor, is useful where a person is considered poor if his income is below poverty line income.

From the Islamic point of view, poverty is perceived almost similarly to the conventional definitions (Clarke \& Tittensor, 2014). One is considered poor if he does not possess sufficient necessities to fulfill his basic needs. Therefore, poverty can be interrelated to Muallaf, as identified and understood in Islam (Aisyah Jami'an., 2005). Many muallaf had nowhere to go after they converted to Islam. Most of them are lack of religious education and care. The muallaf really need and seek for help from the Muslim to enhance their faith. Al-Qardawi (1986) stated that beside alleviate poverty among Mualaf, zakat distribution can improved and increased the Tauhid (The Oneness of Allah), Iman (faith) and Taqwa (level of piety) to Allah (s.w.t). In that sense, zakat has also become an important financial source for the Muallaf, especially in dense Muslim population countries (Muhammad Firdaus et.al, 2012). Zakat fund could act as an incentive to the Muallaf as part of the effort to assist them to become economically productive as long as the fund is channeled in a sustainable form. In short term, the zakat assistance can become a capital for them setup a business or can bear for their education expenses that in a long term can transform them from zakat receivers into zakat payers (MAIS, 2013). Thus, the zakat fund could free the Muallaf from poverty and improve their living standard.

Most of zakat institutions in Malaysia use monetary approach in measuring poverty based on monthly expenditure. For example, in Selangor, one of the states in Malaysia, zakat assistance to the muallaf begins from the first day they become Muslims. The new Muslim would be immediately helped with MYR 500.00 monthly allowance for five years until they become has become economically and morally strong and has received the message of Islam (Mukallaf) (MAIS, 2013). This aid is important for them to bear their cost of living. However this method in which zakat was distribution did not differentiate between the true cost of living between urban and rural. Differences in urban and rural poverty lines that did not reflect the actual urban-rural cost of living differences will provide a misleading picture of the distributional impact of development, which usually involves urban sector expansion. In defining poverty between urban and rural areas, therefore, one should ensure that they take into account differences in the cost of living across these areas (Ahmad, 2013). In a dualistic economy, one 
of the ways the poor benefit from development is through expansion of job opportunities in the modern predominantly urban sector, in addition to increases in productivity in the traditional predominantly rural sector (McMillan et al., 2013).

\section{Research Method}

The current research gathers descriptive analysis to get an overview of Muallaf development through zakat distribution and programmes in current practice. An interview session was conducted on the $25^{\text {th }}$ of June 2013, at $3.30 \mathrm{pm}$ with two officers from The Selangor State Islamic Religious Council (SIRC) whom were Ustaz Mohd Helmi (Assistant Director for Muallaf Welfare in Selangor) and Ustaz Mohd Anwarulhaq (Assistant Director for Muallaf Education in Selangor). The main question in this article is regarding the type of zakat distribution or programmes pertaining to the asnaf muallaf.

In addition, this study also reviews some previous literature on the topic of poverty between urban and rural region. Several methods were used to collect and analyse the literature. First, research was conducted using the Google scholar search engine. Terms such as 'urban poverty', 'rural poverty', 'zakat distribution' and 'urban-rural expenditure' were used, and a limited amount of information was found. The most helpful piece of literature was Asra and Vivian, Poverty Line: Eight Countries. Experiences and the Issue of specificity and consistency that contained results of surveys that collected data on regional poverty line from eight country and factors that influence differences in regional poverty line. Second, books on the topic for this conceptual paper were searched using the Universiti Sains Islam Malaysia (USIM) library. The same terms used in the database search was used to find books related to the topic. Three books were deemed useful and were borrowed from the library for further reading. Third, zakat distribution and poverty databases were reviewed to obtain insight on zakat distribution, expenditure consumption between urban and rural region as well as gaining a brief understanding on poverty pattern between these regions in Malaysia. Also, a dissertation database, for social sciences, was explored in order to gain insight on how to prepare a scholarly paper. Since the topic deals with social policy and economics, the forth method for collecting literature was using economic databases.

The objective of this article is to explore zakat distribution programs for sustaining muallaf belief oneness of God (Tawhid) and faith (Iman). Thus, the purpose of this interview session is to get the response/feedback according the SIRC practices about zakat distribution towards asnaf muallaf in Selangor. The Selangor State Islamic Religious Council (SIRC) was selected because of its achievement as being the highest zakat fund collection in Malaysia. This study was motivated by the monthly official zakat distribution towards asnaf Muallaf did not differentiate the true urban-rural cost of living differences. Thus, this study aims to identify the dispersal of Muallaf in terms of urban-rural poverty that involved in allocation of zakat distribution.

\section{Urban-Rural Poverty Issues: A Review}

Since most of state zakat department in Malaysia did not differentiate the urban and rural cost of living, most of previous zakat poverty studies in Malaysia were based on official poverty line (Johari, 2004; Patmawati, 2006; Patmawati \& Rahisam, 2010; Fahme, 2011, Kader et al., 2012; Fahme et al., 2013). The acceleration of urbanization has been accompanied by increase of urban poverty together with crowding, uneven distribution of development benefits and change in the ecology of urban environments. Figure 1 shows the poverty incidence for urban and rural in Malaysia from 1989 to 2012.

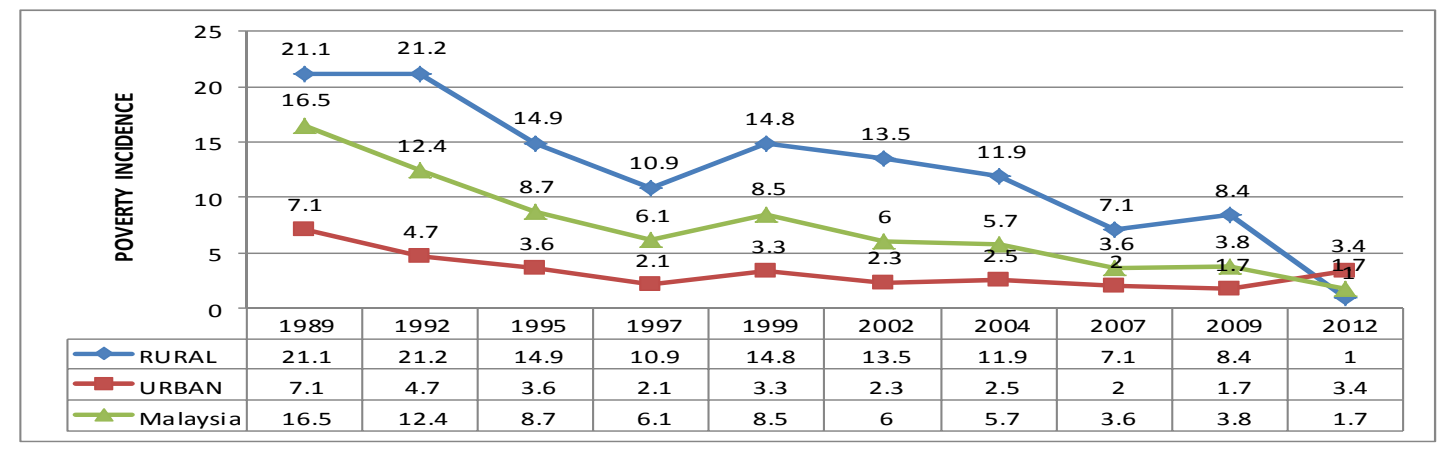

Figure 1. Malaysia: Poverty Incidence (Urban-Rural) 1989 - 2012 (\%)

Since 1989, the Malaysia's poverty has been a predominantly rural phenomenon for example, in 1989, 16.5 per cent of Malaysian households was below the poverty line. The number of poor rural households as a percentage 
of the total number of households was 21.1 per cent, the remaining 7.1 per cent being urban. Throughout 1989 until 2009 we can see that poverty in rural area is higher than urban area however in 2012 the number of poverty incidence in urban area exceeded the number poverty incidence in rural area.

However, in 2012, this phenomenon had shifted to urban area with 3.4 per cent of poverty incidence occured in urban area. The rural poverty rate in 1989 was two-thirds of its 2004 level; it more than halved in the next 10 years and was halved again from 2007 to 2012. The urban poverty rate was halved every 6 years from 1989 to 1995. By 2012, just 1 per cent of rural household live in poverty while the amount of urban poverty increase to 3.4 per cent respectively. This is cause by the rapid urbanization that has occurred over the decades means that the number of the urban poor is now considered significant (EPU, 2013). Based on previous study in urbanization, cost of living and lack of employment opportunities are the main factor for this poverty area shift to happen (Olayiwola, 2008; Ravallion \& Bidani, 1994; Alam, 2011; Nor Aini \& Chamhuri, 2003; Alam et al., 2011).

Urban and Rural poverty are two different types of phenomena. According to the World Development Bank Report (2010), about 495 million urban poverty involved medium and low-income earners. Reviewing the numbers based on percentage, the urban poverty is less than rural areas however the impact of urban poverty is more severe than urban poverty (Choon et al., 2011). For example, a Muallaf who live in a rent house in urban area, owning car and earn more than Poverty Line Index cannot be considered as non-poor people because they have to bear for other dependents, high cost of living and a variety of basic needs and services expenses.

The household expenditure patterns between rural and urban areas are also different. In urban areas, the percentage of households spending more focused on non-food goods such as home, transportation and education. This contrasts with the pattern of spending in rural areas which focus on food expenses. The non-food items only obtained after food needs are fulfilled and there is a surplus of expenditure. Further, urban poverty often involve debt either by banks or financial institutions, while in rural areas, they are not involve debt.

For developing countries such as China, Malaysia, India and Indonesia, urban poverty is a serious problem that it becomes their main focus for policy development. This is because urban poverty would create various problems such as housing problem, increase in crime and social problems, reducing their health status, reducing the level of safety, neglect of children's education and environmental problems, particularly pollution. Thus the urban population will bear with unsafe conditions either within or outside their house.

Rural poverty exists because of several different reasons. It happens due to the neglect of the agricultural sector, the largest economic contributor to the rural sector. Discrimination in land distribution, renting a land for farming that cause low emissions, low income and education levels and also poor health. In addition, the exploitation and monopoly from middlemen and uneconomic land also causes poverty in rural area. Ibn Khaldun (1332-1406 AD) (as cited in Sadeq, 1992) explained the concept of poverty in terms of differences Badawah community (rural) and Hadharah community (urban). He said the living condition in urban area is growing rapidly because of the demands of rural affluence than that mostly consists of poor and destitute population because of their poverty. This occurs because their income is not enough to meet the requirements and cannot be accumulated surplus as profit (Sadeq, 1992).

Based on study about poverty line in Philippines, Balisacan (1999) suggested that food poverty lines in richer areas will tend to be higher because these areas would prefer better quality that are naturally more expensive sources of calories. Thus, a person's poverty would depend on his/her location and the prevailing living standard in the area rather than his command over basic consumption needs wherever he or she happens to live. The spatially consistent poverty estimates for 1994 given by Asra and Francisco (2000) and by Balisacan (1999) lead to different regional poverty rankings than the ones based on the official estimates. The rank correlation of both estimates with the official ranking is the same, 0.59, implying that there is substantial re-ranking of provinces, while the rank correlation between the two estimates is high, 0.78 .

Asra (2000) estimates that in Indonesia, the poverty incidence in rural areas was always higher than in urban areas. The official estimates, however, which use the old methodology, showed that between 1980 and 1993 , urban poverty incidence was higher than rural poverty incidence. This official calculation has been criticized particularly by Ravallion (1992) and Ravallion and Bidani (1994) who have argued that the urban-rural differential of the poverty lines (at about 70 per cent for the period 1984 to 1987) is far above the urban-rural cost of living differences. Ravallion and Bidani (1994) have also dealt extensively with these regionally inconsistent poverty lines, which these authors claim have resulted in misleading poverty measures. Crucial to appreciating this issue is the question of 'consistency' which is necessary to enable a meaningful urban-rural comparison of the poverty profile. Ravallion and Bidani (1994) show that the implied urban and rural food 
bundles yielding 2,100 calories per person per day for 1990 differ considerably from each other, which suggests that standard of living also differs between urban and rural areas.

The issue of urban-rural comparability was also raised by Booth (1993) and Asra and Virola (1992). They argue that using the cost-of-calorie method (a variant of food-energy-intake method of FEI) to derive poverty lines in Indonesia produced poverty lines that were incomparable between urban and rural areas on standard of living. The official poverty lines indicate that except for 1996, for the years since 1976, the ratios of urban to urban poverty lines have always been between 1.50 and 1.77. Asra and Virola (1992) also found that in calculations for 1976 and 1981 the quality of food consumed in urban areas was higher than the quality of food consumed in rural areas. This was indicated by the lower percentage of calories derived from less nutritious food items such as cereals, roots and tuber, and sugar, in rural areas. In sum, by indicating that poverty incidence was higher in urban areas than in rural areas, the BPS calculations for the decade 1980-90 might have shown a ranking that is misleading

\section{Result and Discussion}

In the state of Selangor, the zakat assistant is channelled in a purposed to educate, assisting and monitoring the Muallaf through various programmes starting from the first day they convert to Muslims. (MAIS, 2013). Thus the assistant and education programs setup by the SIRC can be categorized into short and long terms programmes. Basically this level of zakat allocation shows that zakat assistant for Muallaf begin at the first day they had become Muslims. The New Muslim would be immediately being instant with monthly allowance for five years until they manage to act in accordance with Allah's orders and to perform worshipping (Mukallaf). This assistant is important for them to bear for their cost of living. Besides monthly allowance, Islam is also concern about education and health of its devotee. The current amount of zakat distribution for the Muallaf is static for five years while at the same time, it also neglects the difference between the urban and rural cost. On top of that 31 types of programmes have been assign to make sure the Muallaf can be survive to handle the conflict of being new Muslim (MAIS, 2013). Figure 2 show the amount of zakat distribution by categories in Selangor from 2008 until 2011.

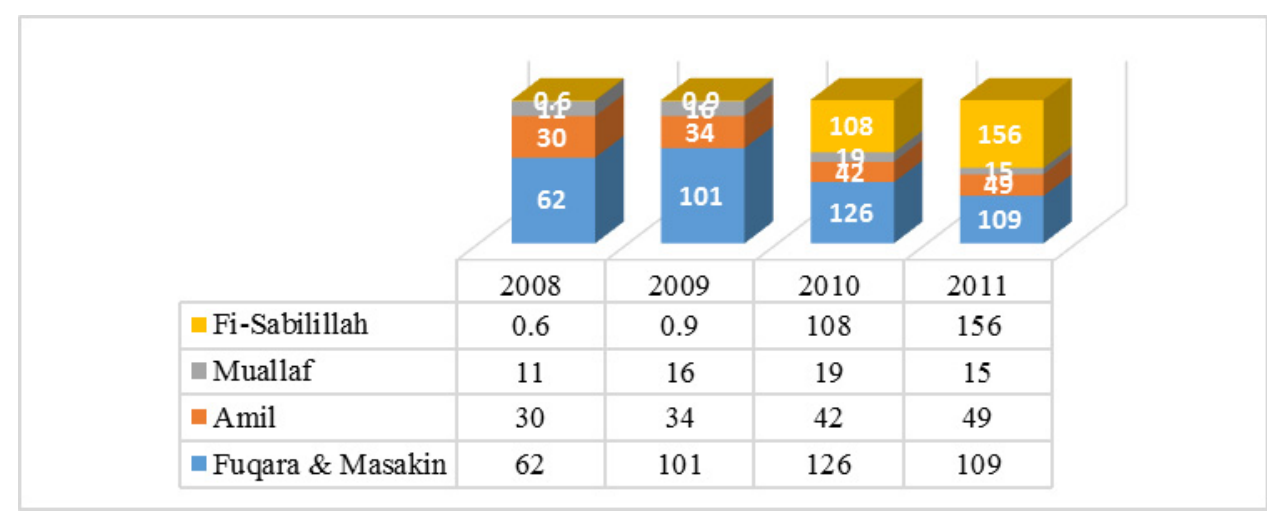

Figure 2. Selangor Zakat Distribution by Category (2008-2011) (MYR MILLION) Source: JAWHAR 2012 (unpublished)

It shows that the amount of zakat allocation to the Muallaf is increasing from MYR 11 million (2008) to MYR 16 million (2009) and MYR 19 million in the year 2010. Only for the year 2011, the amount of zakat allocated to the Muallaf shows a small declining which is from MYR 19 million to MYR 15 million. The rest, we can conclude that allocation of zakat to the muallaf in the state of Selangor (except for year 2011) is consistently increasing each years. The trend of zakat allocation to the Muallaf is actually reflected from the total amount of registered Muallaf in the state of Selangor every year. This research tries to look into the amount of registered muallaf, zakat allocation and the programmes that involved the Muallaf. Generally, what we can conclude that this huge percentage distributed to the Muallaf indicates that zakat has played important roles to assist the new Muslims and help them overcome their suffering and poverty as stated in the Quran (9:60).

In Selangor, the SIRC has effectively manage, educate, and assist the Muallaf in Selangor right after they convert to Islam. This is proven by an increase in the number of registered Muallaf and those who are receiving zakat aids in Selangor as shown in Figure 3. 


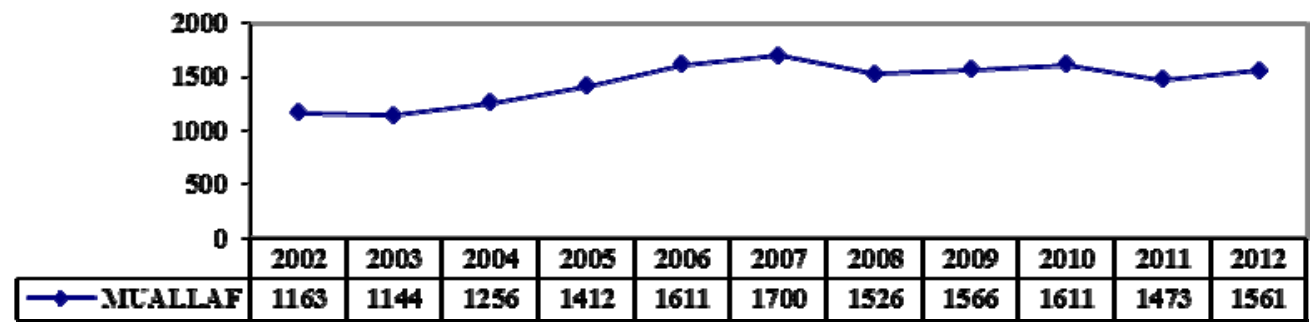

Figure 3. Number of Muallaf in Selangor (2002 - 2012)

Source: Department of Muallaf Development, MAIS

Figure 3 shows, the increasing amount of registered Muallaf receiving zakat aids from year 2002 until 2012 in the State of Selangor had support the important of zakat in attract and managing the non-muslims to convert to Islam. In the year 2011, the Muallaf that been registered is less than the previous years, and the declining allocation also may occur because of in the same years, some of the Muallaf has become accountable person and the one who is pubescent, sane, and has received the message of Islam (Mukallaf) (Maimun, 2014). Overall, this positive increment and practice is the evidence to the view of Zakat assistant towards Muallaf as part of dawa methodology since it is essential for Muslims to propagate Islam (Paizin, 2013). In terms of regional, the urban district had recorded higher number of registered Muallaf compared to rural area. This is causes by numerous program of dawa and flows of information about goodness of Islam that received by non-Muslims (MAIS, 2013). Figure 4 and Figure 5 show the data of registered Muallaf receiving zakat aids based on district and urban-rural in Selangor for 2012.

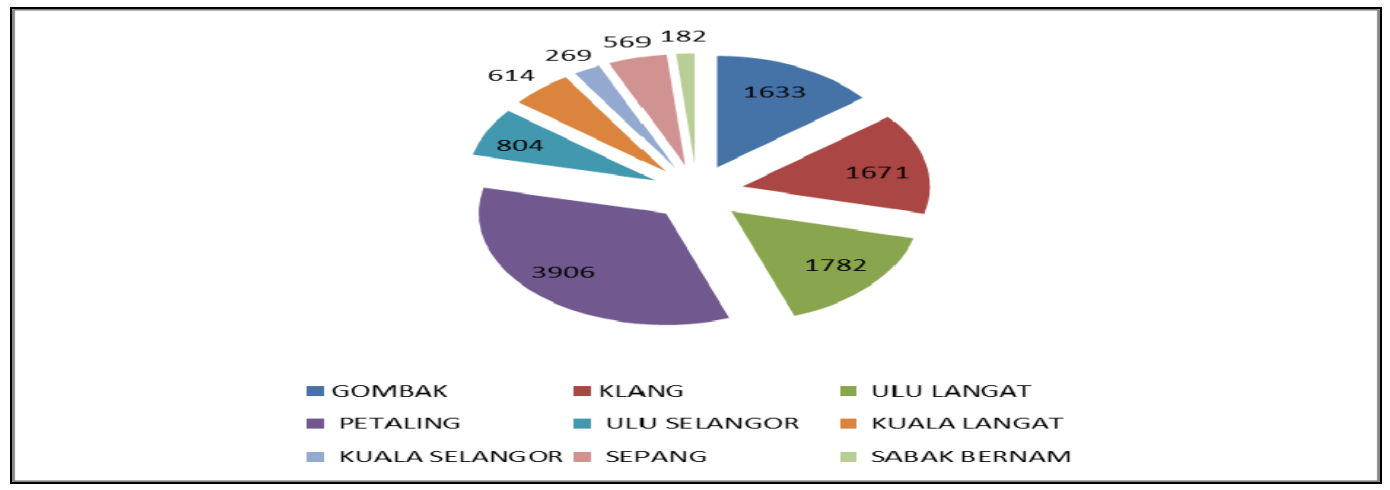

Figure 4. Number of Muallaf in Selangor (2012)

Source: Department of Muallaf Development, MAIS

In Figure 4, all urban district (Gombak, Ulu Langat, Klang and Petaling) had shown a high volume of registered Muallaf receiving zakat aids compared to other rural district in Selangor. This high volume can be seen that if we add the number of all registered Muallaf in rural area, this figure still cannot achieve the number of registered Muallaf receiving zakat aids in Gombak alone. For the percentage, about 79 percent of registered Muallaf is in urban area while 21 percent are in rural area as shown in Figure 5. Thus it is important that zakat aids towards the Muallaf should concern about the important on cost of living between urban and rural area.

Figure 5 shows that a huge of amount been allocated to the development of asnaf Muallaf in the state of Selangor especially in urban area. However, most of zakat distribution on Muallaf goes to urban region which higher in cost of living without considering a set of prices including a broader bundle of goods and services representative of the purchases of consumers in different region. Feedback we get from interview with zakat officer says that through current zakat distribution towards the muallaf, once they had convert to become a Muslim, they will be given MYR 500 per month for next five years without considering the differences of cost of living between the urban and rural region. Thus, this current method of distribution had neglect the need to consider a set of prices including a broader bundle of goods and services representative of the purchases of consumers in different region. For example, in 2013, the Malaysia Poverty Line Index (PLI) had set up that for urban area, the PLI is MYR 740 and for rural area the PLI is MYR 320 (Malaysia Statistics, 2011). 


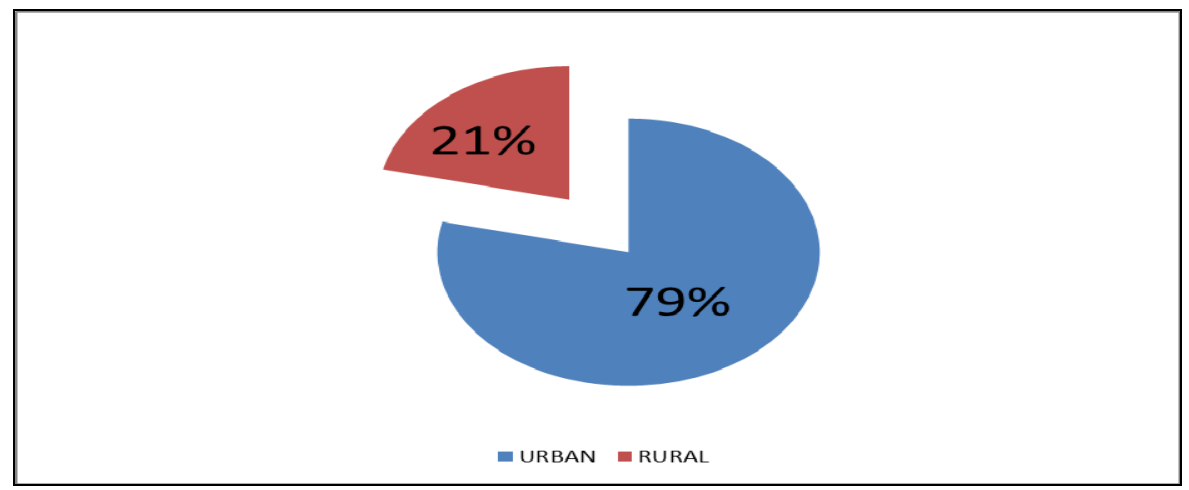

Figure 5. Percentage of Muallaf between Urban and Rural in Selangor (2012)

Source: Department of Muallaf Development, MAIS

\section{The Importance of Urban-Rural Zakat Distribution Among Muallaf}

Mahyuddin Haji Abu Bakar et al. (2011) states that zakat allocation to the Muallaf can help strengthen their faith and creates a sense of belonging among Muslims to assist those who are in need like this group of people. Aishah M et al. (2011) seeks to investigate the conversion patterns among muallafs in Malaysia. Its focus is to find out the demographic information of muallafs and to identify the popular conversion patterns among muallafs in Malaysia. From the study conducted, the following conclusions can be derived: a) majority of the muallafs come from Sabah and belongs to other races found in Malaysia such as Iban, Asli, Myanmar, Kadazan and Thai, b) many of them are unemployed despite having adequate academic level, c) majority of the new muallafs agree that they get the first source of information regarding Islam from people who are close to them like family members, friends, colleagues and neighbours, d) majority of the new muallafs associate their conversion process with the friendliness pattern, followed by the intellectual pattern and lastly the mystical pattern. This coincides with the first source of information they obtain regarding Islam.

Moreover, zakat distribution aims to change the lives of the poverty-stricken by making them afford to live in comfortable life. Al Kasani (n.d.) is also mention that the distribution of zakat serves to cater for the needs of its recipient. For this purpose, zakat does not necessarily be given to all recipients if there are those who need more zakat. The obligation of dividing the zakat equally among the eight deserving categories entails great inconvenience and is not consistent with the behaviour of the early generations of Muslims. Additionally, when the amount of zakat is small, each portion would be negligible. According to Al-Qaradawi (1999), if all the categories of zakat recipient require similar amount of zakat fund, then it must be divided equally among them. However, if some of them require more zakat than the others, they can be given more money from the zakat fund. He clarified that it is left to the zakat institutions or agents to distribute the fund to which recipient whose needs are greatest. For example, if the state collects zakat and there are deservants of zakat in each category, every one of them can ask their share of zakat. The state is not required to divide zakat proceeds among them equally or to give to individuals in every category. Muslim scholars suggest that when he zakat fund are plentiful, it is better to distribute to all categories, but when the fund are limited, it is sufficient to spend them on one category (Ibn Shihab (741-2); Abu 'Ubayd (158 - 224); Siddiq Hasan Khan (1832-1890); Qardawi (2000). Such a decision depends on the needs of these categories and the relative severity of their needs (Al Qardawi, 2000). Further, it is implies that the state has a choice between distributing to all the categories or some of them, depending on what is just. (Qardawi, 1986)

According to al Kasani, the government has the power to identify the ways to distribute zakat. With regard to this, Muhamad Abdul Mun'im (1997) maintains that the obligatory of paying the zakat by Muslims and distributing the zakat by state should become a catalyst to assist the Muslims in four aspects through the goal of zakat distribution: to resolve poverty issue, to establish social justice, to develop a society based on love, mutual solidarity, brotherhood and to eliminate from the poor feelings of hatred that they might have to the rich. In this context, M. Shabri (1998) also argues that zakat has its own strength as it unites the Muslims and non-muslims by building better relations among them and makes the Muslims and non-Muslims work together. For example, zakat fund can be softened and allure the heart of the less wealthy non-Muslims to accept the Islam and at the same time it benefits them by reducing their burden of poverty. Zakat also should be for the purpose of welfare instrument to overcome economic issues or as a means to stabilize the economy of the Muslims. 
Zakat fund was allocated to help the Muallaf in terms of their monetary and morally hardness. Thus providing them with this type of support can reduce their burden of poverty while at the same time making them feel accepted among the Muslims community. A proper implementation of zakat management in a particular state will ultimately improve the socio-economic condition of the Muslim society in that state (Wahid \& Kader, 2010). Since zakat reallocates the resources from the rich to the poor (i.e. zakat deters concentration of wealth in the hands of the rich), it becomes the effective approach to fight against poverty (Sadeq, 2002). Realizing the importance of the implementation of zakat in the Muslim society, proper zakat management is crucial to achieve these objectives. Do the zakat institutions in Malaysia manage the zakat fund efficiently and have they achieved all the objectives? Many studies revealed that there are many problems involved in zakat management especially in terms of zakat distribution.

Actually the after converting, muallaf did not lose their wealth and properties, but most of them lost family connection with their family, relative, friends and place for them to depend. It is because of unacceptable from their family, relative and friends after them become a Muslim. It makes them with nowhere to go and because of "being thrown" by their family, they are easily being poor. Further, as a new Muslims, most of them are lack of Islamic education and safety. The muallaf people really need and seek for help for the Muslim people to enhance their faith. For example, most of the new converted muallaf will receive zakat fund through Muslim Welfare Organization Malaysia (PERKIM) which also provided them with accommodation, education and also morale support. This organization runs through the zakat fund which through zakat fund, they can organize financial assistance and development program to assist the muallaf.

In Selangor, Muallaf conversion is often influenced by marriage and religious financial support (MAIS, 2013). Intermarriage between various ethnic and religious has been practiced for centuries in Malaysia. In such marriage, Islam requires the non-Muslims party to covert to Muslims before the marriage could take place. Thus, support from Islamic Religious Department or congregation members is crucial in helping the people in converts their religion. The support can be expressed in many forms, such as care from congregations or religious organization, Muslims family, society, religious counselling, and assistance from clergy and hospital chaplains. Atqa (2010) found out that Muslims conversion in Indonesia due to receiving information, emotion and financial supports from members of Muslims. The Religious support is actually a perception of social support that comes from three sources: congregation members, religious leaders, as well as from God (Fiala, Bjorck, \& Gorsuch, 2002). Religious support is considered as an important factor in influencing religious conversion.

Al-Qardawi (1986) stated that beside alleviate poverty among Muallaf, zakat distribution can improved and increased the level of Tauhid (The Oneness of Allah), Iman (believes) and Taqwa (level of righteousness) to Allah (s.w.t). Further, zakat also bring gratitude and thankfulness to Allah for the bounties that He bestows on us. Allah has bestowed on humans spiritual and material bounties. Prayers and other physical worships express gratitude for the grace of creation, while zakat and other financial worships express gratitude for the material grace of God. How disgraceful is he who sees the obvious needs of the poor and does not graciously give one-fourth of a tenth of his wealth, or thank Allah who gave him enough bounty to remove him from the misery and pressure of poverty. Zakat has also become an important financial source, especially in dense Muslim population countries (Firdaus et al., 2012). Zakat fund could act as an incentive to the Muallaf as part of the effort to assist them to become economically productive recipients if the fund is channelled in a sustainable form. Moreover, the zakat fund could free the recipients from poverty and improve their living standard.

The most difficult phase for a muallaf is to share it new religion with his/her family. Most of muallaf will feel guilty amongst their family and relatives and being afraid of being rejected. Families can be very reluctant to support religious conversions because they can think that they have lost their child or because of common misconceptions about Islam such as violence and womens rights. Family members will protest, devastated and agree with the conversion and worst when there is anti-Islam in the family member. Further, the new Muslims will even feeling guilt at their family because of what an embarrassment for their family to have somebody who's doesn't fit the status quo inside of the family.

After 11/9 booming episode, there are numerous misconceptions and stereotypes about Islam and Muslims. This misconceptions and stereotypes caused deep distress within Muslim communities and those converting to Islam come across these prejudices that certainly build fear within them. The misconceptions and stereotypes therefore need to be constantly challenged and addressed though muallaf obviously needs the time and space to be able to know and understand Islam so that he / she knows the misconceptions and feels confident to address them in ways that they feel comfortable. 
Muallaf will feel lost regarding where to go to effectively live their faith. One problem they encounter is the ethnicization of some mosques. In these places, they find that cultural identity is stronger than religious standards and so they feel hard to be integrated. Also, some muallaf do not know to which branches of Islam they should refer to and/or are not well aware of the different movements and/or do not have an entire understanding of the principles of Islam.

Muallaf will also be facing practical issues when embracing a new way of life which is also differ from their previous way of life. Some of the issues may include (i) their relationships with non-Muslims may change due to fear and preconceptions about Muslims, and (ii) marriage with a non-Muslim. These practical issues may have the greatest impact for muallaf and such support at a practical level is therefore important. Muallaf mostly in non-Muslims country will experience the barriers of being part of minority. They suffer the changing attitude of people amongst them. They report that as formerly part of the majority, they never had to face before this kind of hatred, attitudes and behaviours.

In a worst-case scenario, muallaf might feel so discouraged that they have a second-guess about their decision to become a Muslims. With all the problems that arise after conversion and lack of morale and material support, there is a sense of desperation that can lead to apostasy. While some of it is unavoidable, there is much that our communities as well as zakat institution can do to help our converts feel welcome and strong as Muslims. Most of it requires simple attitude changes like getting rid of the "back-home" mentality and having ideals that don't reflect reality.

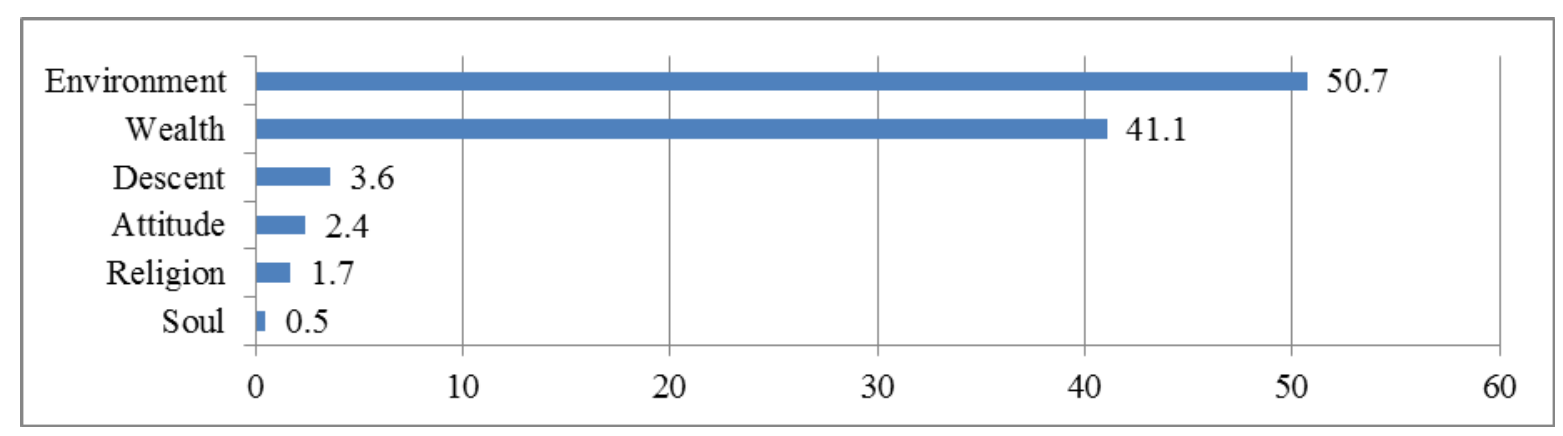

Figure 6. Muallaf Perception to Apostates in Selangor (2002 - 2012)

Source: Department of New Convert Development, MAIS, Aidit Ghazali \& Zulkifli Abdul Hamid, 2012

From figure 6, we can see that influence from economic condition (wealth) become the second reason most of the muallaf being apostates in Selangor. In fact, there is also a certain parties with a hidden agendas seeking to attract the muallaf to return to their original religion by threat or obscure them with moral assistance and financially rewarding. This situation would only endanger the faith of the muallaf. Thus, the current method of zakat distribution should be relook and review from time to time as with considering the differences of cost of living between the urban and rural region.

\section{Conclusion}

The research findings indicate that the number of registered muallaf are higher in the urban compared to rural area. The need for regional cost of living assistant and aids from zakat distribution is crucial for them to survive because most of them are living in urban area which has higher cost. In defining poverty between urban and rural areas, therefore one should ensure that they take into account differences in the cost of living across these areas. Thus, this study suggests the need for proper determinant ratios of (urban-rural) prices and needs in defining the zakat allocation for muallaf.

The signs of emerging pockets of poverty especially in the urban areas and among genders require a new type of poverty analysis that allows the zakat centre to implement relevant zakat distribution method aimed at reducing the emerging urban poverty and income inequalities between genders. Results from this study are important inputs into public resource allocation decisions regarding efforts to improve the living conditions in the urban and rural areas, especially for big family and the livelihood between genders. Reducing the pressure in the urban areas is crucial in measuring the impact of zakat poverty alleviation system and encouraging cooperation among the poor and non-poor. With poverty eradication as the main priority, the zakat centre could draw the intention of 
zakat system from this thesis to systematically identify the poor in order to reduce the incidence, extent and severity of poverty in the country and to minimize the leakage of welfare to the non-poor.

Allah s.w.t had brought zakat system as an economic solution for the Muslims in supporting muallaf in terms of their monetary and morally hardness as stated in Al-Qur'an (9:60). Zakat distribution can improve their economic and social hardness by reducing their burden of poverty while at the same time make them feel accepted among the Muslims community. The institution of zakat purifies one's heart from the love of material, wealth and prepares it to make sacrifices for the cause of Allah. Zakat functions as a fiscal mechanism because it performs some of the major functions of modern public finance, which deals with social security entitlements, social assistance grants for childcare, food subsidy, education, health care, housing, and public transportation in a welfare state. Since zakat reallocates the resources from the rich to the poor, it becomes the effective approach to fight against poverty.

\section{Acknowledgements}

Appreciation and thanks to Universiti Sains Islam Malaysia (USIM) on university's grant: code (PPP/FEM/IWM/30/14012) for the research titled: "Membangun Model Pelan Pembangunan Ekonomi Dalam Membasmi Kemiskinan Di Kalangan Asnaf Muallaf : Kajian Kes Di Negeri Selangor". Special thanks to the Selangor State Islamic Religious Council in providing us the information and interview session.

\section{References}

Abd. Aziz, M. R. (2012). Introduction to Islamic Institutions in Economics and Finance. USIM Bandar Baru Nilai Publisher.

Abu Bakar, M. H., \& Abd. Ghani, A. H. (2011). Towards Achieving the Quality of Life in the Management of Zakat Distribution to the Rightful Recipients (The Poor and Needy). International Journal of Business and Social Science, 2(4).

Aishah, M., Junaida, I., Muna, A. J., Siti Rafidah, M. D., \& Jusoff, K. (2011). Conversion Patterns among Mualafs at Pusat Bimbingan Islam Sultan Abdul Halim Mu'azam Syah Negeri Kedah Darul Aman (Pusba), Aishah et al. Elixir Soc. Sci., 34, 2509-2511.

Al Kasani. (n. d.). Bada'i al Sana'i. Kaherah: Matba'ah al Imam.

Al-Marbawi Dictionary. Pustaka Nasional Singapura, 1354H

Al-Qurtubi. (1954). Al-Jami' Li Ahkām al-Quran (Vol. 8). Misr: Dar al-Kutub Misriyya.

Asra, A. (2000). Poverty and Inequality in Indonesia: Estimates, decomposition, and key issues. Journal of the Asia Pacific Economy, 5(1/2), 91-111

Asra, A., \& Santos-Francisco, V. (2001). Poverty Line: Eight Countries Experiences and the Issue of Specificity and Consistency. Reducing poverty in Asia: Emerging issues in growth, targeting, and measurement, $173-96$.

Bainbridge, W. S. (1992). The sociology of conversion. In H. N. Malony, \& S. Southard (Eds.), Handbook of Religious Conversion, Religious Education Press.

Balisacan, A. M. (1999). Poverty Profile in the Philippines: An update and reexamination of evidence in the wake of the Asian crisis. University of the Philippines School of Economics, Quezon City.

Cambridge International Dictionary of English. (1997).

Clarke, M., \& Tittensor, D. (2014). Islam and development: Exploring the invisible aid economy. Ashgate.

Dawson, L. (1990). Self-Affirmation, freedom and rationality: Theoritically Elaborating "Active" Conversions. Journal for the Scientific Study of Religion, 29(2), 141-163. http://dx.doi.org/10.2307/1387424

Ezeh, A. C. (2007). Urban-rural differences in the socioeconomic deprivation-Sexual behavior link in Kenya. Social Science \& Medicine, 64(5), 1019-1031. http://dx.doi.org/10.1016/j.socscimed.2006.10.007

Fiala, W. E., Bjorck, J. P., \& Gorsuch, R. (2002). The Religious Support Scale: Construction, Validation, and Cross-Validation. American Journal of Community Psychology, 30, 761-786. http://dx.doi.org/10.1023/ A:1020264718397

Firdaus, M., Beik, I. S., Irawan, T., \& Juanda, B. (2012). Economic Estimation and Determinations of Zakat Potential in Indonesia. IRTI Working Paper Series, 1433-07.

Gelpi, D. L. (1998). The Conversion Experience: A Reflective Process for RCIA Participants and Others. New 
York: Paulist Press.

Hasanuz Zaman, S. M. (1991). Economic Functions of an Islamic State (The Early Experience). Leicester: Islamic Foundation.

Ibn Hisham, Abd al-Mālik al-Himyarī. (n. d.). Al-Sira al-Nabawiyya. Beirut: Dar al-Jil.

Ibrahim, P. (2006). The Economic Role of Zakat in Reducing Income Inequality and Poverty in Selangor (PhD Thesis). Faculty of Economics \& Management, University Putra Malaysia.

Inaba, K. (2004). Conversion to new religious movements: Reassessment of Lofland Skonovd conversion motifs and Lofland Stark conversion process. Human Sciences Research, 11(2), 33-47.

Jamian, A. (2005). The acceptance of Islamic life among the Indian Muslim converts and also the level of their understanding of tauhid, ibadahs, and akhlak. (Master Thesis). Fakulti Pengajian Islam, Universiti Kebangsaan Malaysia.

Johari, F. (2004). Keberkensanan Zakat dalam Mengatasi Masalah Kemiskinan di Negeri Malaka. Kuala Lumpur: Akademi pengajian Islam, University Malaya.

Johari, F., Ab Aziz, M. R., Ibrahim, M. F., \& Ali, A. F. M. (2013). The Roles of Islamic Social Welfare Assistant (Zakat) for the Economic Development of New Convert. Middle-East Journal of Scientific Research, 18(3), 330-339. http://dx.doi.org/10.11113/jt.v66.1940

Johari, F., Ab Aziz, M. R., Ibrahim, M. F., \& Mohd Ali, A. F. (2013). Zakat Distribution and Programme for Sustaining Muallaf Belief and Thought. Jurnal Teknologi, 66(1).

Kadri, Z., Ahmad, S., \& Noor, M. A. M. (2012). Zakat as A Catalyst to Economics Development: Towards High-Income Country. Prosiding PERKEM VII, 2, 1263-1273.

Kose, A. (1994, October-December). English converts to Islam 2. Fountain Magazine, 8.

Lofland, J., \& Skonovd, N. (1981). Conversion motifs. Journal for the Scientific Study of Religion, 20(4), 373-385. http://dx.doi.org/10.2307/1386185

Lofland, J., \& Stark, R. (1965). Becoming a World-Saver: A Theory of Conversion to a Deviant Perspective. American Sociological Review, 30, 862-875. http://dx.doi.org/10.2307/2090965

Maimun, M. (2014). Pendekatan Maqashid Al-Syariah Terhadap Pendistribusian Dana Zakat Dan Pajak Untuk Pembangunan Masjid. Jurnal Asas, 4(2), 1.

McGuire, M. B. (1997). Religion: The Social Context (4th ed.). California: Wadworth Publishing Company.

McMillan, M., Rodrik, D., \& Verduzco-Gallo, Í. (2013). Globalization, Structural Change and Productivity Growth, with an Update on Africa. World Development.

Mohd Ali, A. F. (2011). The Role of Zakat in Poverty Reduction in the state of Kelantan, Malaysia. Unpublished Master Dissertation. Universiti Putra Malaysia.

Mohd Ali, A. F., Noor, Z. M., Ab. Aziz, M. R., Ibrahim, M. F., \& Johari, F. (2013). Impact of Zakat Distribution on Poor and Needy Recipients: An analysis in Kelantan, Malaysia. Australian Journal of Basic and Applied Sciences, 7(14), 177-182.

Muhamat@ Kawangit, R., Don, A. G., Hamjah, S. H., Md. Sham, F., Mohd. Nasir, B., Asha'ari, M. F., ... Abd Ghani, M. Z. (2012). Assimilation Level of Chinese Muallaf In Kuala Lumpur. Advances in Natural and Applied Sciences, 6(4), 524-533.

Paizin, M. N. (2013). Practice of Da'wah in Zakat (Islamic Alms) in Federal Territory, Malaysia: An Observation. International Proceedings of Economics Development \& Research, 73.

Patmawati Binti Haji Ibrahim Dan Rahisam Bin Ramli. (2010). Kesan Agihan Zakat Dalam Membasmi Kemiskinan Dan Ketidakseimbangan Agihan Pendapatan Di Negeri Sembilan. Prosiding PERKEM V, 2, 104-113.

Poston, L. (1992). Islamic dakwah in the west: Muslim missionary activity and the dynamics of conversion to Islam.

Ravallion, M. (1992). Poverty comparisons. Living Standard Measurement Study Working Paper, 88.

Ravallion, M. (2007). Urban poverty. Finance and Development, 44(3), 15-17. 
Ravallion, M., \& Bidani, B. (1994). How robust is a poverty profile?. The World Bank Economic Review, 8(1), 75-102. http://dx.doi.org/10.1093/wber/8.1.75

Rosly, S. A. (2008). Malaysia and Islamic Economics. International Centre for Education in Islamic Finance (INCEIF). (Paper presented at the Hadhari Economics Roundtable Conference, Universiti Kebangsaan Malaysia, 25th November 2008, MALAYSIA).

Sadeq, A. H. M. (1992). Introduction: Islamic Economic Thought. In A. M. Sadeq, \& G. Ghazali (Eds.), Issues in Islamic Economics: Readings in Islamic Economic Thought (pp. 1-13). Longman, Malaysia.

Sahad, M. N., Abdullah, S. A. C., \& Abdullah, S. (2013). Malaysian News Report on Muslim Converts' Issues: A Study on Malaysiakini. International Journal of Humanities and Social Science, 3(13).

Sahn, D. E., \& Stifel, D. C. (2003). Urban-Rural Inequality in Living Standards in Africa. Journal of African Economies, 12(4), 564-597. http://dx.doi.org/10.1093/jae/12.4.564

Shalabi, A. W. (2005). The growing religion. Retrieved July 26, 2009, from http://www.salaam.Co.uk/themeof themonth/jun02_index.php

Shirazi, N. S. (1996). Targeting, Coverage and Contributing of Zakat to Household's Income: The Case of Pakistan. Journal of Economic Cooperation among Islamic Countries, 17.

Sicular, T., Ximing, Y., Gustafsson, B., \& Shi, L. (2007). The Urban-Rural Income Gap and Inequality in China. Review of Income and Wealth, 53(1), 93-126. http://dx.doi.org/10.1111/j.1475-4991.2007.00219.x

Siddiqui, M. N. (1978). Some Aspects of the Islamic Economy (2nd ed.). Lahore, Pakistan: Islamic Publications Ltd.

Sintang, S., Khambali@ Hambali, K. M., Baharuddin, A., Senin, N., Shaharud-din, S., Yon, W. A. W., ... \& Nor, M. R. M. (2013). The Dialogue of Hikma: Generating Harmony in Muslim-Non-Muslim Relations. Islam and Christian-Muslim Relations, 24(2), 213-224. http://dx.doi.org/10.1080/09596410.2013.772328

Webster's New World College Dictionary (3rd ed.). (1996).

Yusuf al-Qaradawi. (1986). Fiqh al-Zakat (Vol. I \& II). Lebanon: Mu'assasat al-Risalah.

\section{Copyrights}

Copyright for this article is retained by the author(s), with first publication rights granted to the journal.

This is an open-access article distributed under the terms and conditions of the Creative Commons Attribution license (http://creativecommons.org/licenses/by/3.0/). 